POSTER

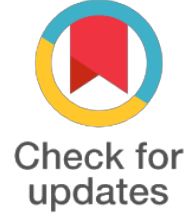

updates

*For correspondence:

phuongnguyen@ibt.ac.vn Competing interests: The authors declare that no competing interests exist.

Received: 2017-06-30

Accepted: 2017-08-04

Published: 2017-09-05

Copyright The Author(s) 2017. This article is published with open access by BioMedPress (BMP).

This article is distributed under the terms of the Creative Commons Attribution License (CC-BY 4.0) which permits any use, distribution, and reproduction in any medium, provided the original author(s) and the source are credited.

\section{Synthesis of Polymeric Nanoparticles of a- mangostin and its Cytotoxicity to Human Cancer Cell Lines}

\author{
Phuong T.M. Nguyen, * Lam D. Tran, * Nguyen K. Dang, Dat T. Nguyen, \\ Mai T. Tran, Anh V.T. Nguyen, and Albert Bolhuis
}

Institute of Biotechnology, Vietnam Academy of Science and Technology, Ha Noi, VietNam

\section{Abstract}

$\alpha$-Mangostin (AMG) extracted from Garcinia mangostana L., has potent anti-cancer properties, however its clinical application is limited due to poor aqueous-solubility. Here, we successfully synthesised and characterised water-soluble ß-cyclodextrin-coated AMG 30-50 nm-size nanoparticles (NMG). Similar cytotoxic activities against LU-1 (human lung adenocarcinoma) and HL-6o (human promyelocytic leukemia) cancer cells of water-soluble NMG and organicsolvent soluble AMG were found with $\mathrm{IC}_{50}$ of 8.86 and $9.86 \mu \mathrm{g} / \mathrm{mL}$, respectively. The data demonstrates that the nanoparticles improve bioavailability while maintain anti-cancer activity of AMG.

\section{Keywords}

$\alpha$-Mangostin, ß-cyclodextrin, cytotoxicity, cancer cells

\section{Funding}

TWAS grant 14-062 RG/BIO/AS_G and NAFOSTED 106-NN.02-2016.19

\section{References}

1. G.C. Ee, S. Daud, Y.H. Taufiq-Yap, N.H. Ismail, M. Rahmani. Nat. Prod. Res. 2006, 20, 1067.

2. P.T.M. Nguyen, M.L. Falsetta, G. Hwang, M. Gonzalez, H. Koo. Plos One . 2014, 9, e1113122014.

3. A.F. Aisha, Z. Ismail, K.M. Abu-Salah, A.M. Majid. J. Pharm. Sci. 2012, 101, 815

4. P. Pan-In, A. Wongsomboon, C. Kokpol, N. Chaichanawongsaroj, S. Wanichwecharungruang. J. Pharmacol. Sci. 2015, 129, 226.

5. S. Qiu, R. Granet, J.P. Mbakidi, F. Brégier, C. Pouget, L. Micallef, T. Sothea-Ouk, D.Y. Leger, B. Liagre, V. Chaleix, V. S ol. Bioorg. Med. Chem. Lett. 2016, 26, 2503. 